\title{
Morphological aspects of the pancreas in the rat and the rabbit: an investigation into the location, ducts, arteries and veins
}

\author{
Ayşe HALIGÜR ${ }^{1}$, Emine KARAKURUM ${ }^{2}$, Ömer Gürkan DİLEK ${ }^{2}$ \\ ${ }^{1}$ Cukurova University, Faculty of Ceyhan Veterinary Medicine, Department of Anatomy, 01960 Ceyhan-Adana/TURKEY \\ ${ }^{2}$ Mehmet Akif Ersoy University, Faculty of Veterinary Medicine, Department of Anatomy, 15030 Burdur / TURKEY
}

Key Words:
anatomy
ducts
pancreas
rabbit
rat
vessels

Anahtar Kelimeler:

anatomi

kanal pankreas

tavşan

rat

damar

Received: 12.12.2018

Accepted: 20.12.2018

Published Online: 31.12.2018

Article Code:495969

Correspondence:

A. HALIGÜR

(ahaligür@gmail.com )

ORCID:

A. HALIGÜR: 0000-0002-3668-4286

E. KARAKURUM: 0000-0003-3324-3271

ÖG. DILEK: 0000-0002-5717-3928

\begin{abstract}
The aim of the present study was to determine both the location of the pancreatic duct and the anatomical variation in the pancreatic ducts of rat and rabbit. Following administration of ether anesthesia, the abdomens were opened. Catheters were placed in the ileocolic vein, junction of the duodenum and jejunum, and into the aorta. All arteries, veins and pancreatic ducts were filled with red, blue and white dyed latex, respectively. The rat pancreas was consisted of three lobes, while the rabbit pancreas was consisted of two lobes. The rat pancreas also involved a diffuse gland situated in the gastrolienal ligament and mesoduodenum. It was observed two major ducts which name posterior pancreatic duct, anterior pancreatic ducts. The ducts that were determined in the right side of the biliaropancreatic duct open from origin the biliaropancreatic duct were measurements $8.09+2.65 \mathrm{~mm}$ right side and left side $7.32+3.61 \mathrm{~mm}$. The rabbit pancreas included a diffuse gland situated among the liver, stomach and duodenum. In the rabbit, the duct of the pancreas (pancreatic duct) entered the duodenum $51.52+3.23 \mathrm{~cm}$ distal to the pylorus. Bunting \& Jones (19) reported that the pancreatic duct opened to the duodenum and $25-27 \mathrm{~cm}$ away from (distal part) the pylorus in rabbit, the present authors found the pancreatic duct opened to the duodenum and measured $46.33-57.17 \mathrm{~cm}$ in our study.
\end{abstract}

Tavşan ve rat pankreas'ının morfolojik görünümü: Lokalizasyonu, kanalları, arterleri ve venleri üzerine bir araştırma

\section{ÖZ}

Bu çalışmanın amacı rat ve tavşanlarda ductus pancreaticus'un yerleşimini ve bu türlerde ductus pancreaticus'un anatomik varyasyonlarını belirlemektir. Eter anestezi uygulaması sonrası cavum abdominis açıldı. Kateter, vena iliecolica, duodenum ile jejenumun birleşim noktasına ve aorta'ya yerleştirildi. Tüm arter, ven ve pancreas kanalları sırasıyla kırmızı mavi ve beyaz boyalı lateks ile dolduruldu. Rat pankreas1 üç, tavşan pankreası ise iki lobdan oluşmaktaydı. Rat pankreası ligamentum gastrolienal ve mesoduodenum arasında yaygin bir bez olarak görüldü. Ductus pancreaticus anterior ve posterior olmak üzere iki kanal olduğu gözlendi. Bu kanalların başlangıcından itibaren sağ tarafta $8.09+2.65 \mathrm{~mm}$ sonra, sol tarafta da 7.32+3.61 mm sonra ductus biliopancreaticus'a açıldığı saptandı. Tavşan pankreası karaciğer, mide ve duodenum arasında yaygın bir bez olarak görülmekteydi. Tavşanda ductus pancreaticus, distal pylorus'ten $51.52+3.23 \mathrm{~cm}$ uzaklıkta duodenum'a aç1lır. Bunting \& Jones (19) tarafindan ductus pancreaticus'un tavşanda pylorus'un başlangıcından 25-27 cm sonra duodenum'a açıldığı bildirilmiştir. Bu çalışmada ise ductus pancreaticus'un açılış deliğinin pylorus'a uzaklığı $46.33-57.17 \mathrm{~cm}$ olarak ölçüldü.

\section{INTRODUCTION}

Rats and rabbits are extremely popular animals for experimental and surgical studies. As those aforementioned species are inexpensive, they are widely used as animal models for many investigations (1). The majority of studies performed to develop techniques of pancreas resection, to study exocrine and endocrine structures, to perform various pancreatectomy techniques and to carry out experimental studies, have used rat and rabbit models $(2,3,4)$. Therefore, studies on the anatomy or topographic anatomy of the pancreas in the rat and the rabbit can provide valuable knowledge.

Obtaining information on the exact location of the vessels, nerves and ducts of the pancreas are crucial for the collection of pancreatic juice (5), experimental acute pancreatitis (6), cannula practices, ligation of the common biliary duct or pancreatic duct (7), and placement of the ligation (8). The surrounding structure of the pancreas is well documented in several textbooks and studies, however there is a lack of topographic anatomy (9). In particular, the variation in localization of the pancreatic duct in rabbits is not known. Surgical, anatomical, physiological or other experimental studies are required to provide detailed anatomy of the pancreas and its variations. Therefore, the main goal of the present study was to provide the localization of the pancreas, pancreatic ducts, arterial and venous "road map"in both the rat and rabbit, which was critical for surgical guidance.

\section{MATERIALS and METHODS}


In the present study, 20 rats (10 female, 10 male) (Wistar albino) and 20 rabbits (10 female, 10 male) (New Zealand) were enrolled. All animals were adult and healthy. The rabbits were 2-2.5 years old and weighed $3120-3700 \mathrm{~g}$. The rats were 3-5 months old and weighed 246-252g. The guidelines of the Committee for Experiments on Laboratory Animals were followed. The study was fully approved by the University Ethics Commission of the Mehmet Akif Ersoy University in Burdur. The abdomens of rats and rabbits were opened following ether anesthesia and after placed dorsally.

The first catheter $(24 \mathrm{G})$ was placed into the ileocecocolic vein, as it is nearly impossible to find this vein after cleaning the vessels. The second catheter $(18 \mathrm{G})$ was placed in the junction of the duodenum and jejunum. Before latex dye was given, the oesophagus and jejunum were ligated in order to obstruct slow backflow and a third catheter (24 G) was placed into the aorta after cutting the apex of heart. All vessels were cleaned with $0.9 \% \mathrm{NaCl}$. After those applications, all arteries, veins and pancreatic ducts (PD) were filled with red, blue and white dyed latex. Finally, all specimens were fixed in 10\% formaldehyde solution. The appearance of the small branches and ducts, embedded in adipose tissue, were supplied by transparence medium. For transparency, $1 \% \mathrm{KOH}$ was applied to the pancreas and surrounding structures at $30^{\circ} \mathrm{C}$ for $24 \mathrm{~h}$ to allow examination of the small branches and ducts. The rabbit pancreatic duct was measured with a digital

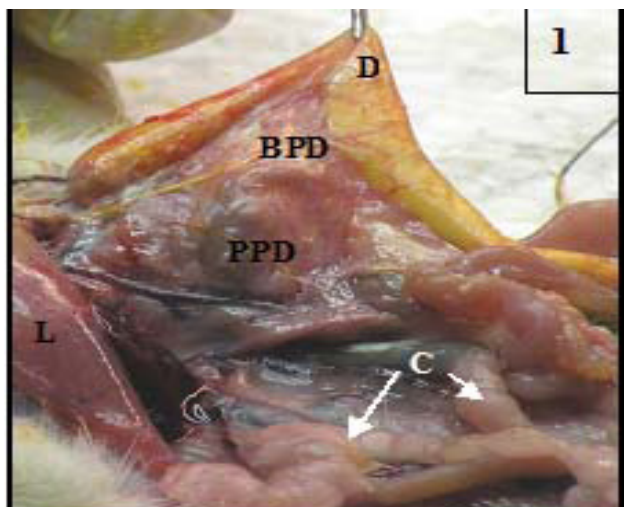

Figure 1 Pancreas in rat. C: Colon, D: Duodenum, L: Liver, BPD: The biliaropancreatic duct, PPD: The posterior pancreatic duct.

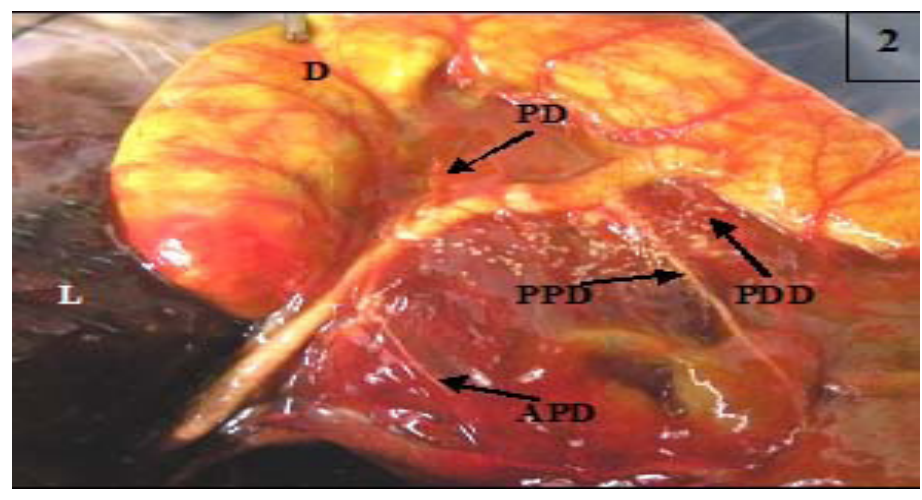

Figure 2 Pancreas in rat, D: Duodenum, L: Liver, APD: The anterior pancreatic duct, PD: Pancreatic duct, PDD: Pancreatic duct (direct opening the duodenum), PPD: The posterior pancreatic duct.

compass (Mitutuya, 150mm). Ducts of the rat pancreas were measured by dissection microscope with micrometric ocular.
Measurements were made only when the diameters of the ducts exceeded $0.1 \mathrm{~mm}$; smaller ducts were only taken into account, not measured. Mean values and standard deviations were determined for all morphometric data and the SPSS 10.0 PC program was used for statistical analyses.

\section{RESULT and DISCUSSION}

In the rat, the pancreas lied in the upper portion of the abdominal cavity on the right, near the stomach, spleen, pars

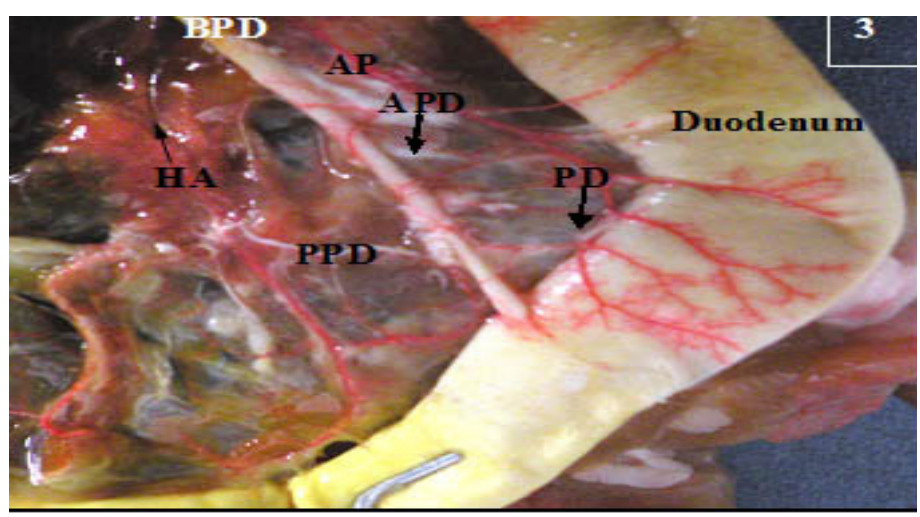

Figure 3 View of the pancreas in the rat following removal of the stomach, AP: The branch of cranial pancreaticoduodenal artery, APD: The anterior pancreatic duct, BPD: The biliaropancreatic duct, HA: The branch of hepatic artery, PD: Pancreatic duct, PPD: The posterior pancreatic duct.

descendens duodeni and colon transversum. The pancreas consisted of three lobes, namely; gastric, splenic and duodenal lobes. These lobes were localized within the peritoneal cavity. The right lobe (duodenal) of the pancreas was situated in the mesoduodenal region of the duodenal lobe. The left lobe (splenic lobe) laid between the stomach and transverse colon. The gastric lobe was situated between the stomach and liver.

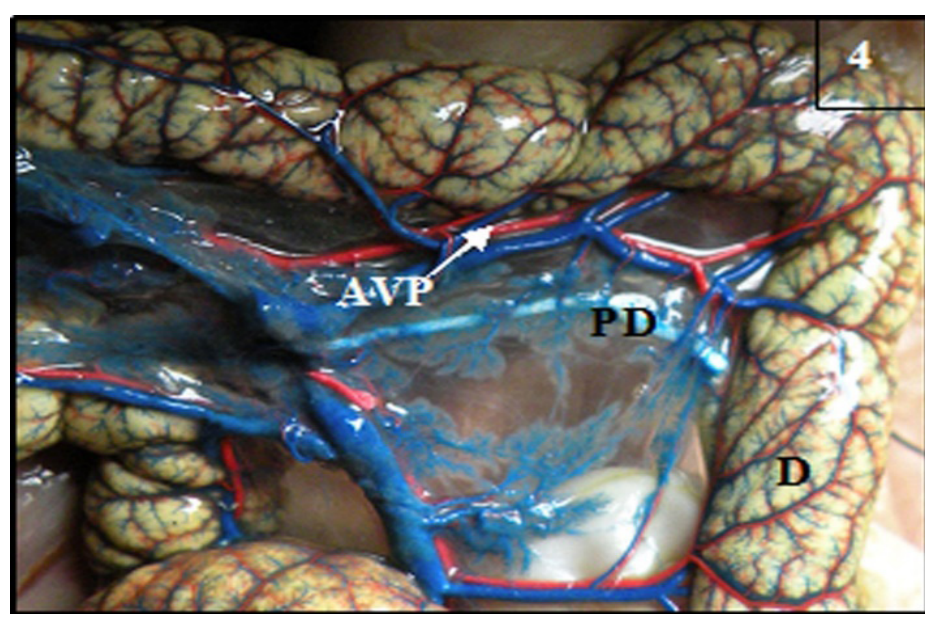

Figure 4 View of the pancreatic duct and vessels in the rabbit, AVP: The caudal pancreaticoduodenal artery and vein, D: Duodenum, PD: The pancreatic duct.

There were two major ducts which name posterior pancreatic duct (Figure 1, PPD), anterior pancreatic ducts (APD) in all specimens; however a varying number of small ducts were observed. The ducts (Fig. 2, 3/ PD) drained each pancreatic lobe and opened into the bile duct. Therefore, the bile duct was referred as a biliaropancreatic duct (BPD). 


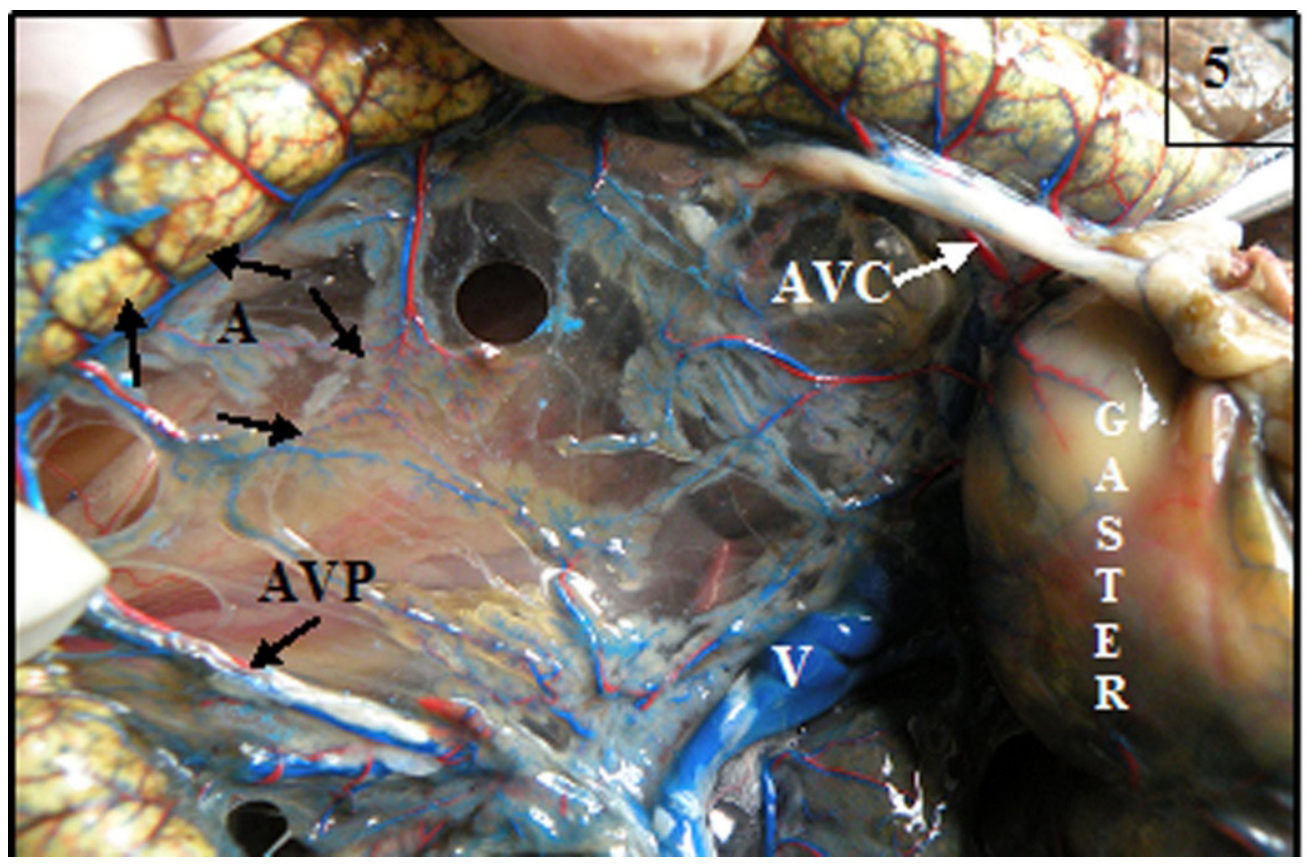

Figure 5 View of the pancreatic duct and vessels in the rabbit, A: Anastomose of caudal and cranial pancreaticoduodenal artery, AVC: The cranial pancreaticoduodenal artery and vein, AVP: The caudal pancreaticoduodenal artery and vein, V: Portal vein.

The ducts of the pancreas were localized on both the right and left sides of the biliaropancreatic duct, entered the biliaropancreatic duct or independently opened into the pars descendens duodeni in the rat. The pancreatic ducts were localized on the left side in 17\% (20 rats) and on the right side in $13.5 \%$ (20 rats). The posterior pancreatic duct was generally localized on the right side and the anterior pancreatic duct was on the left side of the biliaropancreatic duct. The small duodenal ducts drained directly into the duodenum (Fig. 2/ were $0.47 \pm 0.16 \mathrm{~mm}$ on the right and $0.58 \pm 0.11 \mathrm{~mm}$ on the left. There were varying duct sizes and locations that opened to the biliaropancreatic. However, two of those were very large and were designated as the posterior and anterior pancreatic ducts. The posterior pancreatic duct drained from the gastric lobe and the anterior pancreatic duct drained from the splenic lobe. The anterior pancreatic duct was $16.49 \pm 0.92 \mathrm{~mm}$ away from the papilla duodeni. It was positioned on the left side $(62.01 \%)$, right side $(15.12 \%)$ and dorsal part $(32.29 \%)$ of

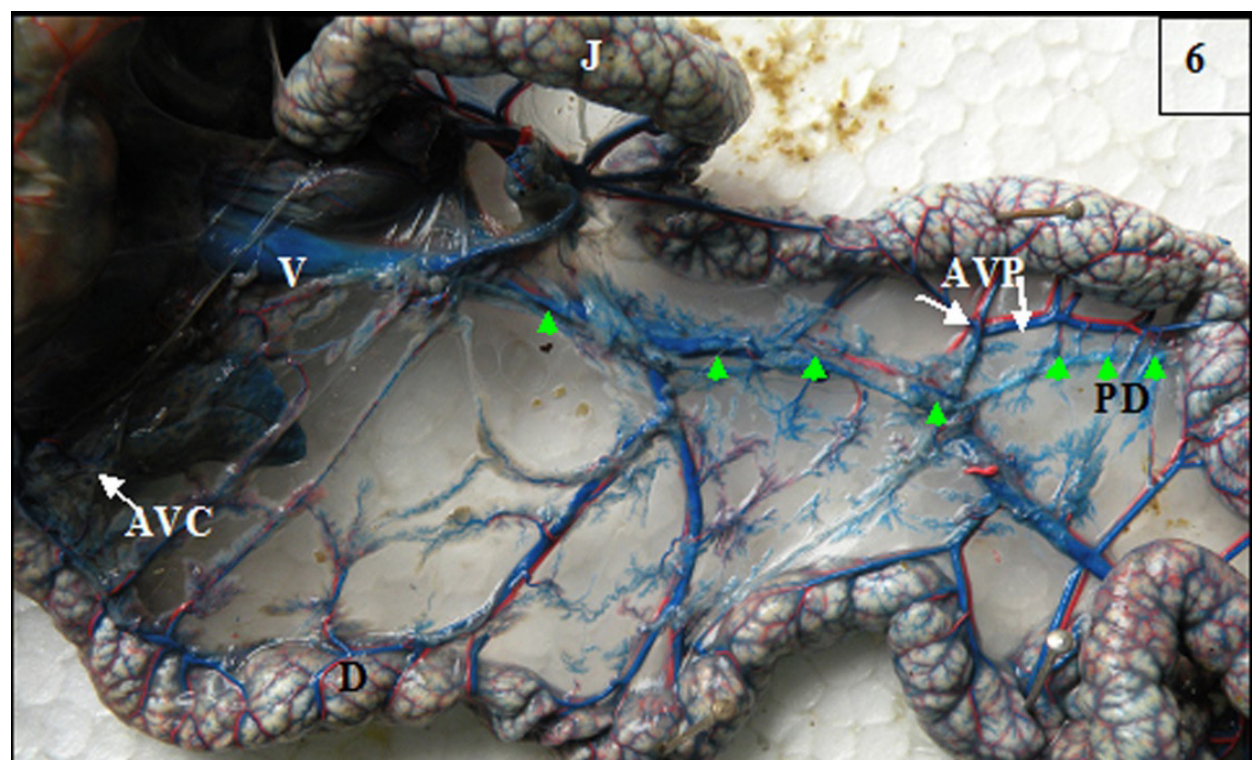

Figure 6 View of the pancreatic duct and vessels in the rabbit, AVC: The cranial pancreaticoduodenal artery and vein, AVP: The caudal pancreaticoduodenal artery and vein, D: Duodenum, J: Jejunum, PD: The pancreatic duct, V: Portal vein, **: The pancreatic duct

PDD). Only 5 specimens opened directly into the duodenum. Statistical means of the duct numbers were $1.35 \pm 0.49$ and $1.70 \pm 0.66$ on the right and left, respectively. The mean standard deviation of the distance between the pylorus and duodenal papilla was $19.15 \pm 3.17 \mathrm{~mm}$, and the diameters of the ducts the biliaropancreatic duct. The posterior pancreatic duct was $7.74 \pm 0.16 \mathrm{~mm}$ away from papilla duodeni. It was generally on the right side $(73.02 \%)$ of the biliaropancreatic duct. Duct lengths between the origins of the duodenal papilla were $8.09 \pm 2.65 \mathrm{~mm}$ on the right and $7.32 \pm 3.61 \mathrm{~mm}$ on the left. 
The arterial blood supply of the rat pancreas was mainly provided by two different sources: the branches of the celiac artery and the cranial mesenteric artery. The pancreas received blood mainly from the celiac artery via the hepatic artery, splenic artery and left gastric artery. The hepatic artery was explored to originate from the pancreatic branches and that all branches (Fig. 3/HA), except for the ramus hepaticus, supplied the pancreatic and duodenal lobes. The cranial pancreaticoduodenal artery was detected nearly parallel to the biliaropancreatic duct (Fig. 3/AP, BPD). The cranial pancreaticoduodenal artery vascularized the final part of the duodenum, and anastomosed with the caudal pancreaticoduodenal artery which originated from the cranial mesenteric artery. The present anastomosis occurred with the cranial branch of the cranial pancreaticoduodenal artery. The latter artery separated into the pars descendens and pars transversa duodeni and supplied a branch to the pancreas, namely the pancreatic branch. The splenic artery divided into two major branches. One branch supplied blood to the spleen. Its course was along the ventral edge of the spleen, and at this point, it gave rise to a very small branch to the splenic lobe. After its origin, the splenic artery divided into two branches. One of these supplied the spleen while the other extended to the greater curvature of the stomach. The branch that supplied the spleen attached to the ventral border the spleen and was observed to split into small branches that attached to the splenic lobe of the pancreas. The others branches of the splenic artery were observed to give off small branches to both the stomach and the gastric lobe of the pancreas. The gastric lobe of the pancreas also received small branches from the origin of the left gastric artery. Venous drainage of the rat pancreas was in parallel with that of the arteries. The hepatic, left gastric, splenic and cranial mesenteric veins all drained to the pancreas. The caudal and cranial pancreaticoduodenal veins discharge the caudal mesenteric vein. The caudal mesenteric vein emptied into the cranial mesenteric vein (18 animals), or the splenic vein ( 2 animals). All of these veins opened to the portal vein.

The pancreas belonging to the rabbit was appropriately similar to a gland. It was pinkish-gray in color and was localized between the stomach, liver and duodenum, and to those consisted of two lobe glands (right and left lobe); the left lobe was localized to ligamentum gastrolienale, between the stomach and colon transversum; the right lobe was in the mesoduodenum. The pancreatic duct entered the duodenum at its distal part (pars ascendens duodeni) (Fig. 4/PD), and was completely separate from the bile duct. It was consisted by the union of two canals that arose from the right and left lobes. The pancreatic duct opened $46.33-57.17 \mathrm{~cm}$ from the origin of the pylorus. Statistical mean of duct opened lengths was $51.52 \pm 3.23 \mathrm{~cm}$. The mean diameter of the ducts in the rabbit was $2.20 \pm 0.48 \mathrm{~mm}$.

The blood supply of the rabbit pancreas was provided by the cranial pancreaticoduodenal artery (Figs. 5, 6/AVC), which was separate from the hepatic artery. This artery gave off a small branch to the pars ascendens duodeni and continued to supply other pancreas structures. It anastomosed with a branch of the cranial mesenteric artery (caudal pancreaticoduodenal artery)
(Figs. 4, 5, 6/AVP). The caudal pancreaticoduodenal artery which divided into a branch of the cranial mesenteric artery, gave off two branches. The first branch of this anastomosed (Fig. 5/A) with the cranial pancreaticoduodenal artery. The second branch went to the duodenal curve under the colon and was almost parallel to the pancreatic duct. The course of this branch gave off small pancreatic branches to the pancreas. The right lobe of pancreas had a small branch of the gastroduodenal artery, which was a branch of the hepatic artery. The left lobe of the pancreas, small branches distributed throughout the splenic artery was giving the course. The veins of the rabbit accompanied the arteries, with the main branches being the splenic vein, cranial pancreaticoduodenal vein, and the caudal pancreaticoduodenal vein (Figs. 4-6/AVC, AVP). Small veins of the pancreas (pancreatic veins) were parallel to the artery of the pancreas. The cranial pancreaticoduodenal vein opened into the gastroduodenal vein and the caudal pancreaticoduodenal vein opened into the superior mesenteric vein. The duodenal lobe of the pancreas drained into the left gastric vein. The left gastric vein ran parallel to the homonymous the artery. All of these veins opened into common to the portal vein.

Literature (10) reported that the rat pancreas lay in the omentum, and between the stomach, spleen and duodenum. The findings of the present study were similar to the literature $(10,11)$ as the pancreas was seen to localize at the upper stomach and spleen, and between the pars descendens duodeni and colon transversum. It was laid in the bursa omentalis of omentum majus.

The rat pancreas has three anatomical lobes- gastric, splenic and duodenal, as shown within the literature (4). Literature (9) also reported three lobes, but named them as biliary, duodenal and gastrosplenic lobes. The rat pancreas lobes in the present study were located similarly to previously reported (4), as gastric, splenic and duodenal lobes. As shown in photograph relevant literature (12), pancreas lobes were related to the spleen, stomach and duodenum in this study.

The rat biliaropancreatic ductus was reported to have a very long course and opening to the pars descendens duodeni. It opened approximately $10-22 \mathrm{~mm}$ after the pylorus was situated next to the pancreas structure (1). Literature (9) reported a length of $28.36 \pm 0.53 \mathrm{~mm}$. In the present study, it was measured at $19.15 \pm 3.17 \mathrm{~mm}$ in the rat.

Literature $(13,14)$ stated that the pancreatic ducts open to the bile duct and form the biliaropancreatic duct. Kara (9) declared that some of the pancreatic ducts opened directly into the duodenum. All of these ducts in the rat findings reported in the literature $(1,15,16)$ were similar to our study.

Kara (9) stated that the anterior pancreatic duct is $17.96 \pm 0.75 \mathrm{~mm}$ away from (distal part) the papilla duodeni. This duct originated from the biliaropancreatic duct on the left $(55.55 \%)$, dorsal $(25.93 \%)$ and right $(18.52 \%)$. In this study, the anterior pancreatic duct was easily seen in the rat pancreas. It was localized on the dorsal part $(32.29 \%)$, left side $(62.01 \%)$ or right side $(15.12 \%)$ of the biliaropancreatic duct and $16.49 \pm 0.92 \mathrm{~mm}$ away from the papilla duodeni. It was generally localized on the right side $(73.02 \%)$ of the biliaropancreatic duct and $7.74+0.16 \mathrm{~mm}$ away from (distal part) the papilla 
duodeni.

The vascular supply of the rat pancreas is supplied generally by the hepatic, splenic and gastric arteries, branching from the celiac artery (12). Martins \& Neuhaus (1) state that the pancreatic branch of the hepatic artery had separate branch for the pancreas. This study significantly differs from classical information as the present authors found that the pancreatic branches originated from the hepatic artery with exception of the ramus hepaticus. These branches supplied to the pancreas. Beyond these findings, thin branches of the splenic artery distributed into the pancreas.

A study of Van cat showed that the portal vein formed to the caudal and cranial pancreaticoduodenal vein (right lobe drain), and open into the caudal mesenteric vein. The findings from the present study were similar to those reported previously (17). The caudal mesenteric vein emptied into the cranial mesenteric vein (18 animals), or into the splenic vein (2 animals).

Dursun et al. (18) reported that the gastroduodenal vein formed with the cranial pancreaticoduodenal vein, which was divided into the corpus and right pancreatic lobes (5). In the present study, the cranial pancreaticoduodenal vein was seen to divide to the right side of the duodenal and gastric lobes in the rat pancreas.

The pancreas in the rabbit was a pinkish-gray colored, diffuse, and two-lobed gland with a right and left lobe. It was located very closely the stomach, liver and duodenum. The right lobe of the pancreas was close to the mesoduodenum, while the left lobe was between the stomach and pars transversa duodeni. The pancreas had one duct in the rabbit that opened to the pars ascendens duodeni. This finding was in accordance with literature $(1,16,12)$.

In contrast to the report of Bunting \& Jones (19) that found that the pancreatic duct opened to the duodenum and 25$27 \mathrm{~cm}$ away from (distal part) the pylorus in rabbit, we found the pancreatic duct to be very long, measuring $46.33-57.17 \mathrm{~cm}$ in our study.

The arteries of the pancreas in the rabbit included the celiac artery that came off the hepatic artery and the splenic artery. The caudal pancreaticoduodenal artery originated to the cranial mesenteric artery. In the present study, similar findings were observed according to the literature $(16,20,21)$. The left gastric artery branched off (rami pancreatici) to supply the pancreas.

The origins and courses of the veins in the rabbit pancreas were parallel to the arterial system and similar to literature (16). In contrast to this literature, we found that branch of the left gastric vein entering the pancreas in our study.

In conclusion, this study reported some significant results. First of all, this study revealed that the hepatic branch (ramus hepaticus) which was separated from hepatic artery was not given ramification to pancreas in the rat. Additionally, the present authors discovered that the rabbit pancreatic duct opened far away from the pylorus, in contrast to what was previously published. Furthermore, we found that the venous drainage of the duodenal lobe in the rabbit pancreas was by the left gastric vein. In this study, the rat pancreas had two main ducts in addition to multiple small ducts opening into the biliaropancreatic duct. In the rabbit pancreas, there was only one duct and this opened directly into the duodenum. The variations of the ducts should be taken into account during experimental studies, when researchers working on with the pancreatic duct in the rat and rabbit.

\section{REFERENCES}

1. Martins PN \&Neuhaus, P. Surgical anatomy of the liver, hepatic vasculature and bile ducts in the rat. Liver Int. 2007;27(3):384-92.

2. Jansson L \& Sandler S. Pancreatic and islet blood flow in the regenerating pancreas after a partial pancreatectomy in adult rats. Surg. 1989; 106(5):861-6.

3.Klempnauer J, Lück R, Brüsch U, Steiniger B. Comparison of graft morphology and endocrine function after vascularized whole pancreas transplantation in the rat by different surgical techniques. J. Surg. Res. 1990; 49(1):69-80.

4.Nagai, H. Configurational anatomy of the pancreas: its surgical relevance from ontogenetic and comparativeanatomical viewpoints. J. Hepatobiliary Pancr. Surg. 2003; 10(1):48-56.

5. Zabielski R, Lesniewska V, Guilloteau, P. Collection of Pancreatic Juice in Experimental Animals: mini-review of materials and methods. Reprod. Nutr. Dev. 1997; 37(4):385399.

6. Yasar, M.; Yildiz, S., Mas, R., Dundar, K., Yildirim, A., Korkmaz, A., Akay, C., Kaymakcioglu, N., Ozisik, T. \& Sen, D. The effect of hyperbaric oxygen treatment on oxidative stress in experimental acute necrotizing pancreatitis. Physiol. Res. 2003; 52(1):111-116.

7. Page BJ, Toit DF, Muller CJ, Mattysen J, Lyners R. An immunocytochemical profile of the endocrine pancreas using an occlusive duct ligation model. J. Panc. 2000; 1(4):191-203.

8. Wenger JM, Meyer P, Morel DR, Costabella PMi Rohner A. Radical splenopancreatectomy with duodenal loop conservation in rats. J. Surg. Res. 1990; 49(4):361-5.

9. Kara ME. The anatomical study on the rat pancreas and its ducts with emphasis on the surgical approach. Ann. Anat. 2005; 187(2):105-112.

10. Greene EC. Anatomy of the Rat. 1st ed. New York; Hafner Publishing Company; 1963.

11. Chiasson RB. Laboratory Anatomy of the White Rat. 5th ed. Missouri: McGraw \& Hill Higher Education; 1987.

12. Walker WF \& Homberger DG. Anatomy and Dissection of the Rat. 3th ed. New York: WH Freeman \& Company; 1997.

13. Case RM. Is the rat pancreas an appropriate model of the human pancreas. Pancreatol. 2006; 6(3):180-190.

14. Githens S, Holmquist DRG, Whelan JF, Ruby JR. Characterization of ducts isolated from the pancreas of the rat. J. Cell. Biol. 1980; 85(1):122-135. 
15. Johnson-Delaney, C.A. Anatomy and physiology of the rabbit and rodent gastrointestinal system. Proceed., 6-17, 2006. http://www.chincare.com/HealthLifestyle/HLdocs2/ gastrointestinal.pdf.

16. McLaughling CA \& Chiasson RB. Laboratory Anatomy of the Rabbit. 3th ed. Toronto: McGraw \& Hill Higher Education; 1990.

17. Ozudogru, Z.; Soyguder, Z., Aksoy, G. \& Karadag, H. A macroscopical investigation of the portal veins of the Van cat. Vet. Med.-Czech.2005; 50(2):77-83.

18. Dursun N, Tipırdamaz S, Daşc1, Z, Yalçın H. Kangal köpeğinde v. portae'nin oluşumuna katılan damarlar üzerinde makroanatomik çalışmalar. Vet. Bil. Derg. 1994; 10(1-2):2225.

19. Bunting $\mathrm{CH} \&$ Jones AP. Intestinal obstruction in the rabbit II. J. Exper. Med. 1913; 18(1):25-28. http://www.ncbi.nlm. nih.gov/pmc/articles/PMC2125125/pdf/25.pdf. 2009.

20. Cadete-Leite A. The arteries of the pancreas of the dog. An injection-corrosion and microangiographic study. Am. J. Anat. 1973; 137(2):151-158.

21. Woodburne, R.T. \& Olsen, L.L. The arteries of the pancreas. Anat. Rec. 1951; 111(2):255-270. 